\title{
Incorporation of Intravenously Injected Albumin, Immunoglobulin G, and Fibrinogen in Guinea Pig Megakaryocyte Granules
}

Prem J. Handagama, Marc A. Shuman, and Dorothy F. Bainton

Departments of Pathology and Medicine, University of California School of Medicine, San Francisco, California 94143-0506

\begin{abstract}
In a previous study we provided evidence for a circuitous pathway by which circulating plasma proteins enter megakaryocyte granules by an endocytic mechanism and are returned to the circulation in platelets (1987. Proc. Natl. Acad. Sci. USA. 84:861-865). Horseradish peroxidase (40,000 mol wt) was injected into guinea pigs and its uptake into megakaryocyte organelles examined by electron microscopy and cytochemistry. In the present study we tested the ability of guinea pig megakaryocytes to take up intravenously injected albumin, IgG, and fibrinogen. We used two types of proteins to study the endocytic pathway: $(a)$ heterologous human proteins, which were detected immunohistochemically using antibodies that do not crossreact with the native guinea pig counterparts; and (b) human and guinea pig proteins labeled with the small (250 mol wt), inert molecule, biotin, which were detected using an antibody against biotin. We detected all three of the injected proteins in bone marrow megakaryocytes in patterns identical to those of native counterparts. The injected protein consistently appeared in platelets $24 \mathrm{~h}$ later and was secreted in response to thrombin. We conclude that there are at least two mechanisms by which guinea pig megakaryocyte granules acquire proteins (a) endogenous synthesis, as demonstrated by others, and (b) endocytosis of plasma proteins synthesized by other types of cells.
\end{abstract}

\section{Introduction}

Stimulated platelets secrete several proteins, which are stored in their $\alpha$-granules (1-6). Some of these proteins are specific for platelets, and the others are counterparts of plasma proteins. The platelet-specific proteins include platelet factor 4 and $\beta$-thromboglobulin. The plasma protein counterparts include fibrinogen, fibronectin, albumin, Factor V, vWf, and others (7). Platelet-specific proteins appear to be synthesized solely by megakaryocytes, the bone marrow cells from which platelets are derived (8). Some plasma protein counterparts, such as fibrinogen (9-11), Factor V (12), and vWf (13), have also been shown to be synthesized by megakaryocytes, as well as other cells.

Preliminary work was published in abstract form (1987. Blood. 10:154a).

Address reprint requests to Dr. Handagama, Box 0506/HSW-501, Pathology Department, University of California, San Francisco, CA 94143-0506. 1989.

Received for publication 25 July 1988 and in revised form 2 March

J. Clin. Invest.

(c) The American Society for Clinical Investigation, Inc.

0021-9738/89/07/0073/10 \$2.00

Volume 84 , July $1989,73-82$
Recently we demonstrated that when the tracer protein horseradish peroxidase (HRP) ${ }^{1}(40,000 \mathrm{~mol} \mathrm{wt})$ is injected intravenously into guinea pigs, it is rapidly taken up by bone marrow megakaryocytes and incorporated into granules (14, 15). Based on this finding, we hypothesized that megakaryocytes may acquire some $\alpha$-granule proteins from plasma via a similar endocytic pathway.

We undertook the present study to determine whether megakaryocytes could take up albumin $(64,000 \mathrm{~mol} \mathrm{wt})$, IgG $(180,000 \mathrm{~mol} \mathrm{wt})$, and fibrinogen $(340,000 \mathrm{~mol} \mathrm{wt})$ injected intravenously into guinea pigs. We used two experimental approaches to localize the injected protein in the presence of its native counterpart. In the first approach, we injected heterologous human proteins and then detected them immunohistochemically in bone marrow sections using antibodies that did not crossreact with their respective guinea pig counterparts. In the second approach we injected homologous guinea pig proteins labeled with biotin, a small ( $250 \mathrm{~mol} \mathrm{wt})$ inert molecule, and then detected them immunohistochemically using an anti-biotin antibody. We detected all three of the injected proteins in bone marrow megakaryocytes in localization patterns similar to those of their native counterparts.

\section{Methods}

Animals. 35 male Hartley guinea pigs, each weighing $400-450 \mathrm{~g}$, were used in the experiments.

Plasma proteins. Human albumin (crystallized) and IgG, purified guinea pig albumin, guinea pig IgG, guinea pig fibrinogen, and lactoferrin (from human milk) were all obtained from Sigma Chemical Co., St. Louis, MO. Human fibrinogen (grade L) was from KabiVitrum, Stockholm, Sweden.

Biotinylation. Plasma proteins were biotinylated by modifying the method of Leary et al. (16). The protein $(10-20 \mathrm{mg} / \mathrm{ml})$ was dialyzed against $1.0 \mathrm{M} \mathrm{NaCl} / 0.03 \mathrm{M} \mathrm{N}$-Tris[hydroxymethyl]methyl-2aminoethane sulfonic acid, $\mathrm{pH}$ 7.42. Biotinyl-epsilon-aminocaproic acid $N$-hydroxysuccinate ester $(50 \mathrm{mg} / \mathrm{ml}$ in dimethyl-formamide) was added in a 1:100 dilution (vol/vol), and the mixture was incubated at $20^{\circ} \mathrm{C}$ for $30 \mathrm{~min}$, then at $4^{\circ} \mathrm{C}$ for $90 \mathrm{~min}$. All samples were then dialyzed extensively against the $\mathrm{NaCl} / \mathrm{TES}$ buffer, and finally against

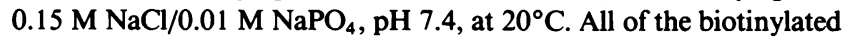
albumin and fibrinogen migrated as intact proteins on Western immunoblots. No degradation products were detected. In control experiments, biotinyl-epsilon-aminocaproic acid $N$-hydroxysuccinimide ester in buffer was injected in place of biotinylated protein. The amount of injected biotin was equivalent to the amount of total biotin ester incubated with each protein during the biotinylation procedure and therefore was at least as large, or possibly larger, than the amount injected in experiments with the labeled proteins.

Administration of proteins to guinea pigs. A single dose of human albumin $(1 \mathrm{~g})$, human $\mathrm{IgG}(300 \mathrm{mg})$, or human fibrinogen $(75 \mathrm{mg})$ was injected into guinea pigs to obtain circulating concentrations similar to native counterparts. In other experiments, smaller doses of human albumin (100 mg), biotinylated guinea pig albumin, biotinylated

1. Abbreviations used in this paper: HRP, horseradish peroxidase. 
guinea pig IgG, biotinylated guinea pig fibrinogen, or biotinylated human fibrinogen were injected. The dose of injected biotinylated protein ranged from 30 to $175 \mathrm{mg}$. To test whether the megakaryocyte uptake of circulating proteins shows specificity, we administered 100 $\mathrm{mg}$ of lactoferrin $(76,000 \mathrm{~mol} \mathrm{wt})$ intravenously to a guinea pig. All proteins were administered in volumes of $5 \mathrm{ml}$ via an indwelling jugular catheter.

Processing of bone marrow. The animals were killed at various times after injection by exsanguination. The vasculature was flushed with heparinized HBSS, immediately followed by fixative (4\% paraformaldehyde in $0.1 \mathrm{M}$ phosphate buffer, $\mathrm{pH} 7.4$ ) via a catheter in the abdominal aorta. The femoral bone marrow core was cut into small pieces and incubated in the same fixative for $6 \mathrm{~h}$ at $4^{\circ} \mathrm{C}$. The tissue was embedded in plastic (JB4; Polysciences, Inc., Warrington, PA) and sectioned at $2 \mu \mathrm{m}$ by previously described methods (17).

Staining. For immunohistochemical staining of plastic-embedded bone marrow sections we modified the technique of Beckstead et al. (17). The modifications were as follows: (a) Sections were incubated with 5\% (wt/vol) nonfat milk (Carnation Co., Los Angeles, CA) and $0.2 \%$ Tween 20 in $\mathrm{Ca}^{2+}$ - and $\mathrm{Mg}^{2+}$-free PBS for $30 \mathrm{~min}$ at $37^{\circ} \mathrm{C}$ (instead of horse or goat serum to reduce nonspecific background). (b) The secondary antibodies used were biotinylated goat anti-rabbit IgG (1:400; Vector Laboratories, Inc., Burlingame, CA), biotinylated rabbit anti-goat IgG (1:400; Vector Laboratories, Inc.), or biotinylated horse anti-mouse IgG (1:200; Vector Laboratories, Inc.). All secondary antibodies were adsorbed against guinea pig serum to remove any crossreactivity with guinea pig Ig. Control procedures included the appropriate substitution of normal rabbit or mouse serum for the primary antibody and the elimination of primary and/or secondary reagents.

Localization of native plasma proteins in megakaryocytes. Bone marrow from untreated guinea pigs was stained for native albumin, IgG, and fibrinogen using the technique described above. The antibodies used were rabbit anti-guinea pig albumin $(2.0 \mathrm{mg} / \mathrm{ml}, 1: 10,000$; Cappel Laboratories, Cochranville, PA), rabbit anti-guinea pig IgG (1 $\mathrm{mg} / \mathrm{ml}, 1: 1,000$; Zymed Labs., Inc., San Francisco, CA) and rabbit anti-human fibrinogen antibody $(20 \mathrm{mg} / \mathrm{ml} ; 1: 500$; Cappel Laboratories). The last antibody, although raised against human fibrinogen, recognized guinea pig fibrinogen.

\section{Localization of injected proteins}

In the first approach, injected human proteins were detected in bone marrow in the presence of their native counterparts by using noncrossreacting antibodies. In the second approach, biotinylated homologous guinea pig proteins were injected. The injected protein was specifically localized using an anti-biotin antibody.

\section{ALBUMIN}

Human albumin. Injected human albumin was detected in the presence of native guinea pig albumin using mouse anti-human albumin MAb ( $>1: 10^{5}$ in ELISA, 1:2 $\times 10^{3}$; Cedarlane Laboratories, Ltd., Ontario, Canada), which does not crossreact with guinea pig albumin. Crossreactivity was also tested using Western blotting techniques. In control studies, bone marrow from untreated animals was stained with this antibody.

Guinea pig albumin. Injected biotin-labeled albumin in bone marrow sections was localized by incubation with an affinity-purified goat anti-biotin antibody $(0.25 \mathrm{mg} / \mathrm{ml} ; 1: 200$; Zymed Laboratories, Inc.), and then with biotinylated rabbit anti-goat IgG. An alternative method of detection was staining with HRP-conjugated streptavidin.

In all experiments with biotinylated proteins, parallel control experiments were done using bone marrow from untreated guinea pigs and guinea pigs injected with free, unconjugated biotin.

Ultrastructural localization. Biotin-labeled guinea pig albumin (500 mg) was administered intravenously to guinea pigs. Bone marrow megakaryocytes (14) and platelets (18) were isolated as previously described 2 and $24 \mathrm{~h}$ after the injection. Cells were fixed in $4 \%$ paraformaldehyde in $0.1 \mathrm{M}$ phosphate buffer (pH 7.4) for $6 \mathrm{~h}$ at $4^{\circ} \mathrm{C}$. They were then embedded in LR gold (London Resin Company Ltd., Hampshire, UK) at low temperature according to the manufacturer's instructions. The biotin-labeled albumin was localized by post-embedding immunocytochemistry using the goat anti-biotin antibody (1:100) and HRP-conjugated streptavidin as described above for light microscopy. The reaction product was developed by incubation in $0.05 \% 3,3^{\prime}$ diaminobenzidine and $0.1 \% \mathrm{H}_{2} \mathrm{O}_{2}$ in $0.05 \mathrm{M}$ Tris- $\mathrm{HCl}$ at $\mathrm{pH}$ 7.6. Thin sections were exposed to a $1 \%$ aqueous solution of osmium tetroxide and stained for 5 min with Reynold's lead citrate (19).

In control studies megakaryocytes and platelets isolated from untreated guinea pigs were processed and stained identically.

\section{IMMUNOGLOBULIN G}

Human IgG. Injected human IgG was detected in the presence of native guinea pig IgG using biotinylated goat anti-human IgG (1.5 $\mathrm{mg} / \mathrm{ml}, 1 \times 10^{3}$; Vector Laboratories, Inc.). The $3 \%$ crossreactivity with guinea pig IgG exhibited by this antibody was neutralized completely by adsorption against guinea pig serum. As this antibody was biotinylated, incubation with it was followed by incubation with HRP-conjugated streptavidin. No secondary antibody was used. In control studies, bone marrow from untreated animals was stained identically.

Guinea pig $\operatorname{IgG}$. Bone marrow from guinea pigs killed $24 \mathrm{~h}$ after being injected with biotinylated IgG was stained with goat anti-biotin antibody as described above.

\section{FIBRINOGEN}

Human fibrinogen. We tested a mouse MAb against human fibrinogen (Serotec Ltd., Bicester, UK) to detect the uptake of injected human fibrinogen.

Biotinylated fibrinogen. Guinea pigs were killed at various time intervals after being injected with biotinylated guinea pig fibrinogen or biotinylated human fibrinogen. The biotinylated protein was localized immunohistochemically in bone marrow using the goat anti-biotin antibody described above.

HUMAN LACTOFERRIN

Bone marrow obtained $24 \mathrm{~h}$ after administration of lactoferrin was stained with rabbit anti-human lactoferrin $(1 \mathrm{mg} / \mathrm{ml}, 1: 50$; Accurate Chemical and Scientific Corporation, Westbury, NY). The control was bone marrow from an untreated animal processed identically.

Detection of biotinylated fibrinogen in circulating platelets by immunoblotting and immunocytochemistry

Blood was drawn from guinea pigs at 2 and $24 \mathrm{~h}$ after injection of biotinylated fibrinogen. Platelets were purified and washed by differential centrifugation (18). Platelets $\left(3 \times 10^{9} /\right.$ tube $)$ were then incubated with $10 \mathrm{U}$ of thrombin for $2 \mathrm{~min}$ and the supernatant and pellet analyzed for biotinylated fibrinogen. The supernatants were concentrated $\sim 2.5$ - to 5-fold. Samples were solubilized in 2.0\% SDS and electrophoresed in SDS-5\% polyacrylamide gels (3\% stacking gel) at 20 $\mathrm{mA} / \mathrm{gel}$. After washing of the gel, proteins were transferred to nitrocellulose using a Mini transblot apparatus (Bio-Rad Laboratories, Richmond, CA) at $100 \mathrm{~V}$ for $1 \mathrm{~h}$. The nitrocellulose was washed, then blocked with 5\% gelatin. The nitrocellulose was then incubated with avidin-peroxidase (Cappel Laboratories) diluted 1:500 for $1 \mathrm{~h}$, washed, and developed using 4-chloro-1-naphthol and $\mathrm{H}_{2} \mathrm{O}_{2}$.

To show that the endocytosed protein was present within $\alpha$-granules, we colocalized injected labeled fibrinogen and native albumin, a known $\alpha$-granule protein (3), using a double-labeling technique on frozen thin sections (20). Biotin-labeled fibrinogen was localized using rabbit anti-biotin antibody (Enzo Biochem, Inc., New York, NY) and $5 \mathrm{nM}$ gold probe conjugated to protein A (protein A5; Janssen Pharmaceutica, Beerse, Belgium). Native guinea pig albumin was localized with rabbit anti-guinea pig albumin (Zymed) and $10 \mathrm{nM}$ gold probe conjugated to protein A (protein A10) (Janssen Pharmaceutica). Controls included platelets from untreated guinea pigs processed identically, and substitution of nonimmune rabbit serum for specific primary antibody. 


\section{Results}

We used antibodies against guinea pig albumin, IgG, and fibrinogen to study the normal distribution of these three proteins in the megakaryocytes of untreated animals. We then used two techniques for immunolocalization of injected albumin, IgG, and fibrinogen in megakaryocytes. The two techniques yielded comparable results in localizing the injected proteins.

\section{Albumin}

Native albumin. When bone marrow from untreated guinea pigs was stained with an antibody against guinea pig albumin, the megakaryocytes showed distinctly granular staining throughout the cytoplasm (Fig. $1 a$ ). Several other cell types, including endothelial cells, also showed staining; they are summarized in Table $\mathbf{I}$.

Human albumin. Injected human albumin was detected in the presence of its native counterpart by using an anti-human albumin MAb. Bone marrow from untreated guinea pigs showed no reaction product when stained with this antibody (Fig. $1 b$ ); therefore, it did not crossreact with guinea pig albumin. Furthermore, no crossreactivity was detected by the much more sensitive Western blot technique (not illustrated). In guinea pigs killed 1-6 $\mathrm{h}$ after the injection of human albumin, the vast majority of bone marrow megakaryocytes exhibited uptake of the protein. However, occasional megakaryocytes showed minimal or no staining. The pattern of staining was usually granular, but was occasionally diffuse or membranous. Bone marrow megakaryocytes from guinea pigs killed 24-96 $\mathrm{h}$ after the injection consistently showed extensive staining for human albumin in a distinctly granular pattern (Fig. $1 \mathrm{c}$ ). The intensity of staining in megakaryocytes decreased slightly over the $96-\mathrm{h}$ period of observation. In most

Table I. Immunohistochemical Localization of Albumin, IgG, and Fibrinogen in Normal Guinea Pig Bone Marrow

\begin{tabular}{|c|c|c|c|}
\hline & Megakaryocytes & Other bone marrow cells & $\begin{array}{c}\text { Bone marrow } \\
\text { extracellular } \\
\text { space* }\end{array}$ \\
\hline Albumin & $\begin{array}{l}\text { Granular staining } \\
\text { pattern }\end{array}$ & $\begin{array}{l}\text { Endothelial cells } \\
\text { Fibroblasts } \\
\text { Occasional blastlike } \\
\text { cells, macrophages, } \\
\text { fat cells }\end{array}$ & +++ \\
\hline IgG & $\begin{array}{l}\text { Granular staining } \\
\text { pattern }\end{array}$ & $\begin{array}{l}\text { Plasma cells } \\
\text { Endothelial cells } \\
\text { Occasional } \\
\text { macrophages } \\
\text { Rare fat cells }\end{array}$ & ++ \\
\hline Fibrinogen & $\begin{array}{l}\text { Granular staining } \\
\text { pattern; } \\
\text { marked } \\
\text { variation } \\
\text { among cells in } \\
\text { intensity }\end{array}$ & $\begin{array}{l}\text { Endothelial cells } \\
\text { Some macrophages } \\
\text { Rare fat cells }\end{array}$ & + \\
\hline
\end{tabular}

* Staining intensity is graded from + to ++++ . of the experiments a total of $1 \mathrm{~g}$ of albumin was injected. However, even when the animal received the small $(100 \mathrm{mg})$ dose of human albumin, megakaryocytes stained for the injected protein but with less intensity (not illustrated).

At 1-6 $\mathrm{h}$ after the injection, and to a lesser degree at later periods, staining of intercellular spaces for human albumin was observed within the marrow, and in small amounts in bone marrow fibroblasts, osteoblasts, fat cells, and an occasional blast. Sinus endothelial cells consistently stained for human albumin (Fig. $1 \mathrm{c}$ ). Some bone marrow macrophages also appeared to take up human albumin. This staining seems to be specific, because the endogenous peroxidase activity of neutrophils, eosinophils, and red cells was completely inhibited.

Biotinylated guinea pig albumin. To test the possibility of differences in uptake of heterologous human albumin and homologous albumin by guinea pig megakaryocytes, we compared the uptake of injected biotinylated guinea pig and human albumin. Both proteins were taken up by megakaryocytes. Megakaryocytes from animals given $175 \mathrm{mg}$ of biotinylated guinea pig albumin and killed $24 \mathrm{~h}$ after injection showed relatively weak staining (Fig. $1 d$ ). When the dose was $<50$ $\mathrm{mg}$, biotinylated albumin could not be detected. No difference in uptake of homologous and heterologous albumin could be detected by immunohistochemical techniques.

Electron microscopic localization of biotinylated albumin. When stained for biotin-labeled guinea pig albumin, megakaryocytes collected as early as $2 \mathrm{~h}$ after injection contained numerous electron-opaque granules (not illustrated). At $24 \mathrm{~h}$ after injection the majority of megakaryocyte granules contained biotin-labeled albumin (Fig. $2 a$ ). Some granules were negative and granules varied in staining intensity at both 2 and $24 \mathrm{~h}$. Occasional megakaryocytes lacking stained granules were seen at both time intervals.

In control experiments megakaryocytes from untreated guinea pigs processed and stained identically showed no reactivity (Fig. $2 b$ ).

\section{IgG}

Native IgG. When stained with anti-guinea pig IgG antibody, bone marrow megakaryocytes from untreated guinea pigs showed a granular staining pattern (Fig. $1 e$ ). Plasma cells showed strong staining as expected. Fat cells occasionally showed staining. These findings are summarized in Table I.

Human IgG. Injected human IgG was detected in the presence of native IgG using a non-crossreacting antibody.

No crossreactivity of the adsorbed antibody with guinea pig IgG was observed, and bone marrow from untreated guinea pigs was completely negative when stained with this goat anti-human IgG antibody (Fig. $1 f$ ).

In bone marrow from guinea pigs killed $24 \mathrm{~h}$ after the injection of human IgG megakaryocytes showed staining in a granular distribution pattern (Fig. $1 \mathrm{~g}$ ) but varying in intensity among cells. Sinus endothelial cells exhibited small but consistent staining. Occasional bone marrow macrophages and fibroblasts also showed staining. The absence of staining in plasma cells confirmed that the antibody did not crossreact with guinea pig IgG. Moderate amounts of staining were present in extracellular spaces in bone marrow (Fig. $1 \mathrm{~g}$ ).

Biotinylated guinea pig IgG. When homologous biotinylated IgG was injected, the labeled protein was detected in megakaryocytes after $24 \mathrm{~h}$ (not illustrated). 

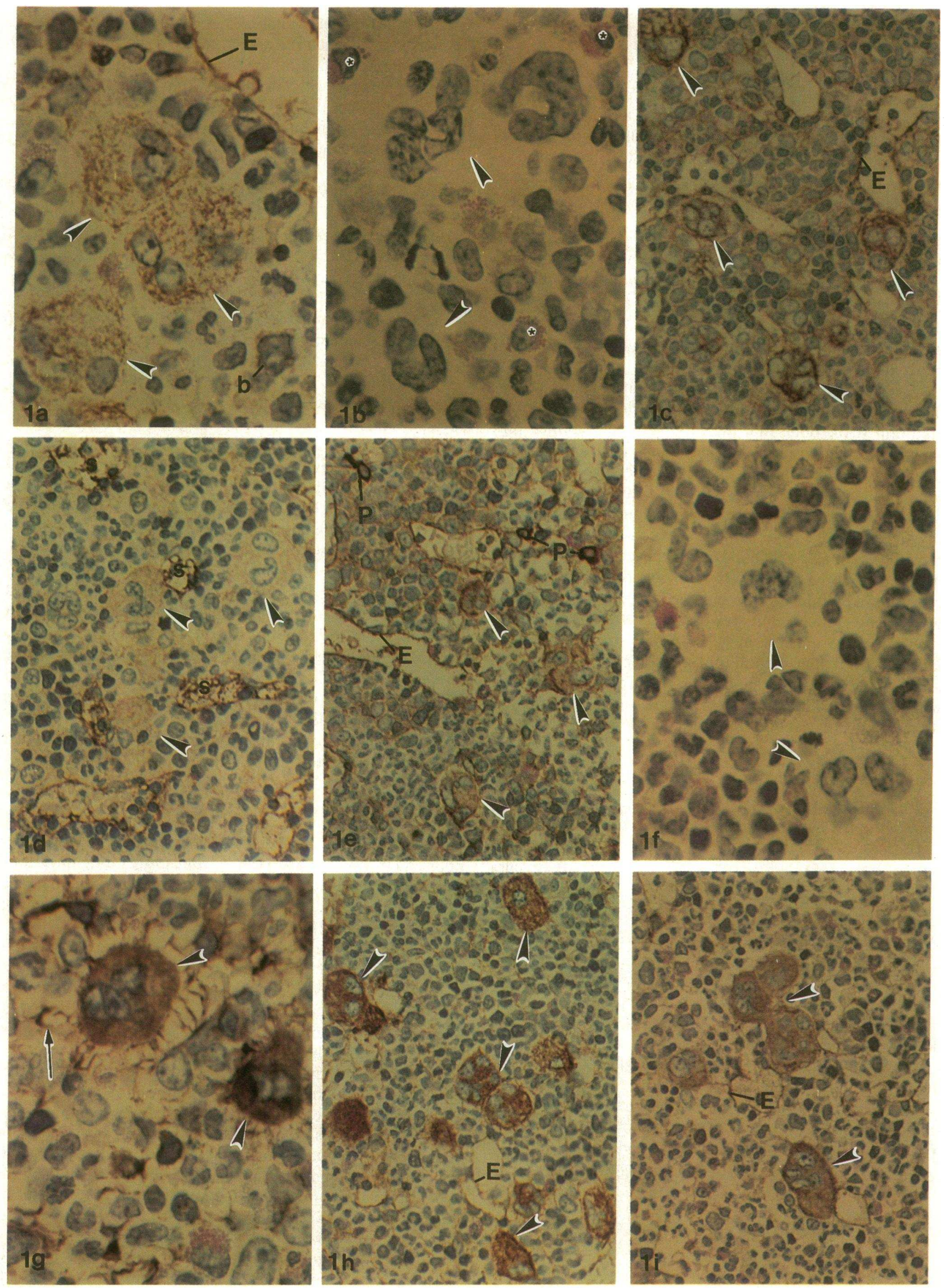


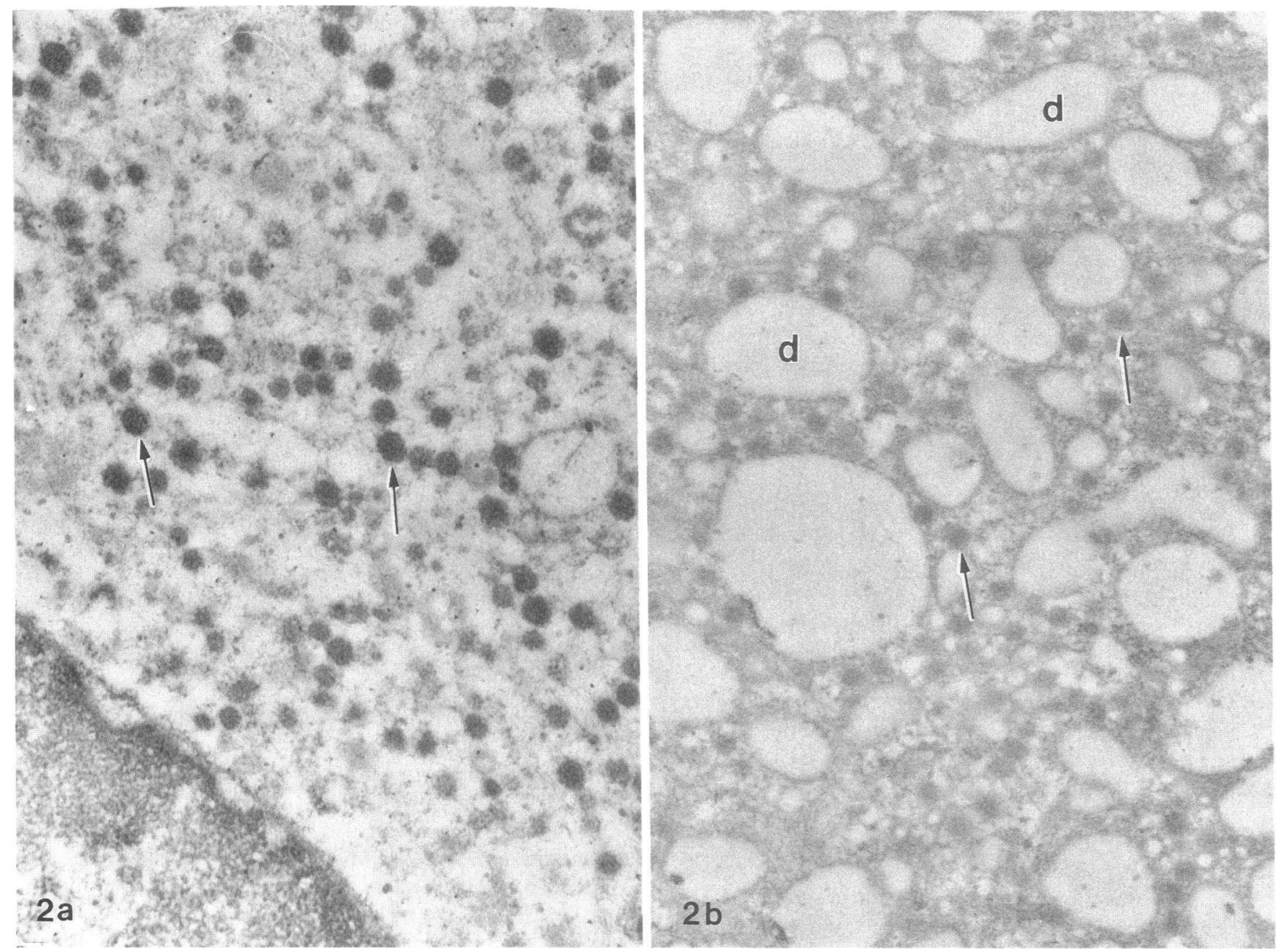

Figure 2. Megakaryocytes were isolated, fixed in paraformaldehyde, and embedded in LR-gold. Thin sections were incubated with anti-biotin antibody, followed by biotinylated secondary antibody and streptavidin peroxidase. The reaction product was developed using $3,3^{\prime}$ diaminobenzidine- $\mathrm{H}_{2} \mathrm{O}_{2}$. The sections were counterstained for $30 \mathrm{~s}$ with osmium tetroxide and for $5 \mathrm{~min}$ with lead citrate. Note: this post-embedding immunocytochemical technique does not allow preservation of membrane structure. (a) Section of megakaryocyte isolated $24 \mathrm{~h}$ after injection of biotin-labeled albumin. Many granules (arrows) are strongly reactive. $\times 20,000$. (b) Section of megakaryocyte from an untreated control guinea pig processed and stained identically. No reactivity is seen in megakaryocyte granules (arrows) or in the demarcation membrane system (d). $\times 19,000$.

Figure 1. Light photomicrographs of perfusion-fixed guinea pig bone marrow, embedded in plastic and tested for the localization of antigen by immunoperoxidase. The brown peroxidase reaction product is localized at antigenic sites. The tissue was counterstained with hematoxylin and eosin. (a) Staining with anti-guinea pig albumin antibody to determine the normal distribution of albumin in untreated animals. In addition to the megakaryocytes (arrowheads), sinus endothelial cells $(E)$ and occasional blasts $(b)$ also show staining for albumin. $\times 900$. (b) Marrow from an untreated animal stained with anti-human albumin MAb. The absence of reaction product shows that there was no crossreactivity of the antibody with guinea pig albumin and therefore is the control for $(c)$. Eosinophils $\left(^{*}\right)$ can also be seen. $\times 900$. (c) Staining with anti-human albumin MAb. Marrow from guinea pigs killed $24 \mathrm{~h}$ after being injected with human albumin shows consistent uptake of the injected albumin by megakaryocytes (arrows). Sinus endothelial cells $(E)$, as well as several unidentified cells, also showed staining for the injected protein. $\times 350$. (d) Staining with anti-biotin antibody in animals killed $24 \mathrm{~h}$ after being injected with biotinylated guinea pig albumin. Note the uptake of the labeled albumin by megakaryocytes (arrowheads). In areas of marrow that were poorly flushed, the contents of the sinusoids stained also (s). $\times 350$. (e) Marrow from an untreated guinea pig stained with anti-guinea pig IgG. Sinus endothelial cells $(E)$ and megakaryocytes $(a r r o w h e a d s)$ show staining. Plasma cells $(p)$ show intense staining. $\times 350 .(f)$ Marrow from an untreated guinea pig stained with goat anti-human IgG antibody. The absence of staining in megakaryocytes (arrowheads) shows that the antibody did not crossreact with guinea pig IgG and is therefore a control for $(g) . \times 900$. $(g)$ Staining with goat anti-human IgG in guinea pigs killed $24 \mathrm{~h}$ after being injected with human IgG. The megakaryocytes (arrowheads), as well as intercellular spaces (arrow) in the bone marrow, are stained for human IgG. $\times 900$. (h) Marrow from untreated animal stained with anti-fibrinogen antibody shows the normal distribution of fibrinogen in bone marrow. Megakaryocytes (arrowheads) and sinus endothelial cells $(E)$ show staining. $\times 350$. (i) Staining with anti-biotin antibody in guinea pigs killed $24 \mathrm{~h}$ after being injected with biotinlabeled human fibrinogen. The injected protein can be seen in megakaryocytes (arrowheads) and sinus endothelial cells $(E)$. $\times 350$. 


\section{Fibrinogen}

Native fibrinogen. We used a rabbit anti-human fibrinogen polyclonal antibody that crossreacts with guinea pig fibrinogen to study the normal distribution of native fibrinogen. Megakaryocytes stained strongly for fibrinogen, which showed a granular distribution (Fig. 1 h). There was marked variability between megakaryocytes. The differences were more obvious at higher dilutions $(1: 5,000$ and 1:10,000) of anti-fibrinogen antibody, where even a few negative megakaryocytes could be seen. However, these differences disappeared to a large extent with lower anti-fibrinogen antibody dilutions (1:500), similar to that used in the present study. At this dilution, although the variable staining between megakaryocytes persisted, almost all megakaryocytes stained for fibrinogen. Bone marrow endothelial cells, some macrophages, and an occasional fat cell also stained for fibrinogen (Table I).

Human fibrinogen. We abandoned the use of heterologous protein to study megakaryocyte uptake of fibrinogen because the antibodies to human fibrinogen that we tested crossreacted with guinea pig fibrinogen.

Biotinylated guinea pig fibrinogen. Biotinylated homologous fibrinogen was detected in megakaryocytes $24 \mathrm{~h}$ after injection. Staining for the labeled protein was distributed in a granular pattern (not illustrated).

Biotinylated human fibrinogen. We observed no significant difference between guinea pig and human fibrinogen in uptake by guinea pig megakaryocytes. Therefore, we used human fibrinogen in the majority of experiments because large amounts of the pure human protein were available.

As early as $\mathbf{2 ~} \mathrm{h}$ after biotinylated fibrinogen was injected, the label could be localized in megakaryocytes. At this time, the staining was often membranous (not illustrated). Megakaryocytes from animals killed $24 \mathrm{~h}$ after injection showed staining (Fig. $1 i$ ), usually in a striking granular distribution, but occasionally along the membranes. Variation in staining intensity among megakaryocytes suggested that uptake was not uniform. In animals killed $48 \mathrm{~h}$ after injection, the staining was slightly less intense than at $24 \mathrm{~h}$.

Sinus endothelial cells often showed weak staining for labeled fibrinogen. Bone marrow macrophages occasionally showed staining.

In a few experiments streptavidin-conjugated HRP was used as the primary reagent instead of the anti-biotin antibody. The weaker staining with this reagent demonstrated that the anti-biotin antibody was more sensitive.

In control experiments for biotinylated proteins, bone marrow from untreated guinea pigs and animals given unconjugated biotin showed no reaction when stained with antibiotin antibody. In other experiments, where normal rabbit or mouse serum was substituted for primary antibody or secondary reagents were eliminated, no reaction product was present.

Human lactoferrin. When stained with rabbit anti-human lactoferrin, bone marrow from the animal given lactoferrin showed staining of some sinus endothelium and marrow macrophages. Megakaryocytes showed complete absence of staining (not illustrated). Neutrophilic myelocytes and more mature cells consistently stained in a granular pattern. In control experiments marrow from untreated animals, when stained with anti-lactoferrin antibody, only the neutrophils were stained, showing that the antibody crossreacted with guinea pig lactoferrin.

Platelets

Based on our findings that plasma proteins such as albumin and fibrinogen are endocytosed by megakaryocytes, one would expect the presence of injected biotinylated proteins in peripheral blood platelets. Blood samples were obtained 2 and $24 \mathrm{~h}$ after injection of fibrinogen, and the platelets were isolated, washed, and examined for biotinylated fibrinogen. Western blot analysis of platelets showed that biotinylated fibrinogen was present in the supernatant of thrombin-stimulated platelets $24 \mathrm{~h}$ after injection consistent with secretion from platelet storage granules (Fig. 3, lane 1). In contrast, biotinylated fibrinogen was present in the platelet pellet (lane 5), but not in the supernatant of platelets that were not stimulated with thrombin $24 \mathrm{~h}$ after injection of biotinylated fibrinogen. A small amount of biotinylated fibrinogen was associated with the platelet pellet in the 2-h sample (lane 3). It is unclear as to the nature of the fibrinogen since it was not secreted with thrombin stimulation. In other experiments no labeled fibrinogen was seen in either the 2-h platelet supernatant or pellets (data not shown). The results also indicate that endocytosed biotin-labeled fibrinogen is secreted intact $\left(M_{\mathrm{r}} 340,000\right)$.

Immunocytochemical staining for biotin-labeled albumin showed that the vast majority of platelets $2 \mathrm{~h}$ after injection do not contain the injected protein (Fig. $4 a$ ), although a few platelets containing stainable granules were seen (not illustrated). However, $24 \mathrm{~h}$ after injection the majority of platelets contained granules that stained for labeled albumin (Fig. $4 b$ ). Quantitation was difficult on electron micrographs due to the numerous grazing sections of platelets that showed few or no granules. At the light microscopic level $>80 \%$ of platelets at 24 $\mathrm{h}$ stained for injected labeled proteins. There was marked variability in the staining intensity among these platelets.

When platelets were double labeled, using protein A5 to label injected biotinylated fibrinogen and protein A10 to label endogenous albumin, both sizes of gold were present within the same granules (Fig. $4 c$ ). This demonstrates that the endocytosed fibrinogen is indeed within $\alpha$-granules. Granules in

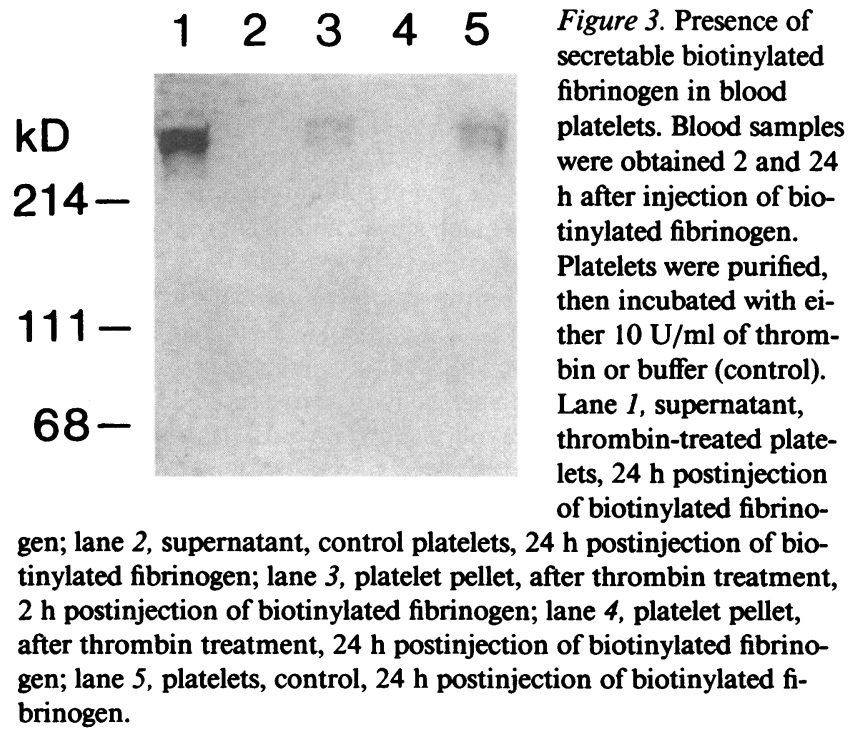



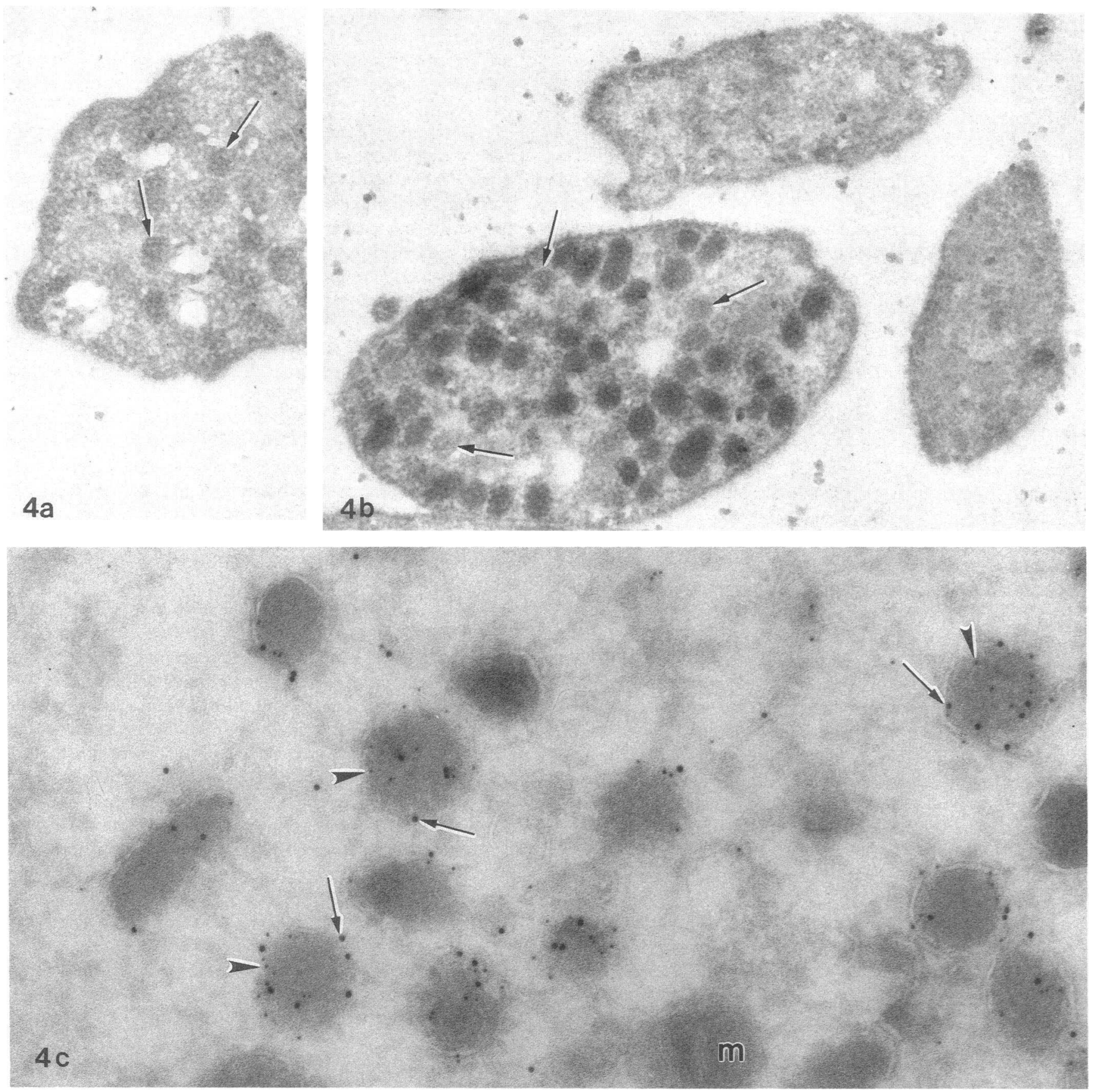

Figure 4. $(a, b)$ Thin sections of platelets embedded in LR-gold, stained for biotin using anti-biotin antibody, secondary antibody, and streptavidin peroxidase. $(c)$ Frozen thin section of platelet double-labeled for biotin and albumin using 5- and 10-nM gold probes. (a) Section of platelet isolated $2 \mathrm{~h}$ after the injection of biotin-labeled albumin. No reactivity is seen in platelet granules $($ arrows $)$. $\times 37,000$. (b) Section of platelet isolated $24 \mathrm{~h}$ after the injection of biotin-labeled albumin. Many platelet granules are strongly reactive. A few negative granules can also be seen (arrows). Two platelet sections in which granules are absent can also be seen. $\times 37,000$. (c) Double-labeling for biotin and endogenous albumin on a frozen thin section of platelet obtained $24 \mathrm{~h}$ after injecting biotin-labeled fibrinogen. Colocalization of small gold probe for biotin-labeled fibrinogen (arrowheads) and large gold probe for guinea pig albumin (arrows) within granules can be clearly seen. $m$, mitochondria. $\times 92,000$.

control platelets obtained from untreated guinea pigs labeled only with protein A10 showing the presence of endogenous albumin, but not labeled fibrinogen (not illustrated). When primary antibodies were substituted for nonimmune serum no labeling was observed (not illustrated).

\section{Discussion}

We have demonstrated that albumin, IgG, and fibrinogen present in megakaryocyte granules are derived, at least in part, from the circulation by endocytosis. This conclusion is consis- 
tent with the recent observation that the platelet $\alpha$-granule content of IgG and albumin is directly proportional to the plasma concentration of these proteins (21).

The three proteins tested in the present study are normally found in high concentrations in plasma. To compensate for dilution with native counterparts, in some experiments initially we injected large amounts of heterologous protein. The abnormal increase of circulating protein may have caused significant osmotic shifts in these animals (22). It could, therefore, be argued that uptake of plasma proteins by megakaryocytes may not be physiological. For this reason we performed other experiments using lower concentrations of plasma proteins. Although less intense, staining for injected protein was easily observed in megakaryocytes when considerably smaller doses of both biotinylated and heterologous proteins were injected. However, at doses of $<50 \mathrm{mg}$, the injected biotinylated protein was difficult to detect, perhaps because of a sensitivity threshold of the immunohistochemical technique.

In a previous study HRP that had been injected into guinea pigs was seen in coated vesicles in megakaryocytes and subsequently in $\alpha$-granules $(14,15)$. A similar pathway may be involved in the uptake of plasma proteins by megakaryocytes. The uptake and incorporation of exogenous protein into granules of other cell types, such as basophils, mast cells, and granule-containing lymphocytes, has been previously demonstrated $(23,24)$.

We also detected injected albumin, IgG, and fibrinogen in bone marrow cells other than megakaryocytes. For instance, sinus endothelial cells consistently stained for the injected proteins. Positive staining for guinea pig albumin, IgG, and fibrinogen in bone marrow endothelial cells from untreated animals indicates that their presence is physiological. These endothelial plasma proteins may be in the process of crossing the sinus wall by transcytosis $(25,26)$. It has been shown that significant pools of albumin (27), IgG (28), and fibrinogen (29, 30) are present extravascularly. The significance of albumin, IgG, and fibrinogen in fibroblasts, fat cells, and macrophages is unclear.

The pathway described in the present study has far-reaching implications. For instance, in addition to carrying various nutrients albumin acts as a transport protein for many drugs and other exogenous substances in plasma (31). Thus, albumin-bound toxins and cytotoxic drugs might be concentrated in megakaryocytes by this pathway.

Plasma fibrinogen is a major blood protein synthesized by hepatocytes. There is controversy about whether platelet fibrinogen differs from its plasma counterpart (32). Some observations suggest that the two differ (33-39), while others suggest they are similar $(40,41)$.

In other studies, when fibrinogen was injected into afibrinogenemic human subjects, no significant uptake was seen in platelets 2 or $20 \mathrm{~h}$ later $(39,42)$. It was concluded that there is no exchange between platelet and plasma fibrinogen pools. However, these experiments do not exclude the possibility that megakaryocytes take up fibrinogen (42). In our studies, using Western blot analysis, we found that only small amounts of biotin-labeled fibrinogen were present in platelets collected $2 \mathrm{~h}$ after injection. However, $24 \mathrm{~h}$ after injection labeled fibrinogen was easily detected in platelets. This was consistent with our immunohistochemical observations, where only a small number of platelets had rare granules containing the injected protein, whereas at $24 \mathrm{~h}>80 \%$ of platelets had granules containing labeled protein. It would be expected that since the guinea pig platelet lifespan is about $4 \mathrm{~d}(14), 25 \%$ of the platelets would be replaced after $24 \mathrm{~h}$. If endocytosis occurred only in megakaryocytes and not in platelets, one would expect only $25 \%$ of platelets to contain the labeled protein after $24 \mathrm{~h}$. However, $>80 \%$ of platelets at $24 \mathrm{~h}$ appeared to contain labeled protein. Therefore, it appears that, in addition to shedding of platelets from megakaryocytes containing labeled protein, circulating platelets may also directly endocytose labeled proteins slowly. Secretion of the biotin-labeled fibrinogen after thrombin treatment indicates that endocytosed fibrinogen is in a functional compartment that is part of the secretory pathway. Colocalization of the labeled fibrinogen and albumin, a known $\alpha$-granule protein (3), demonstrates that the endocytosed protein is present within $\alpha$-granules.

Most of the platelet IgG is intracellular (43). Very little is present on the surface (44-46). Recently it has been shown that IgG is stored in $\alpha$-granules and is secreted by stimulated platelets (18). Since there are no reports of megakaryocyte synthesis of IgG, it was suggested that IgG might be acquired from the plasma and transported to the megakaryocyte $\alpha$ granules (18). Our present observations support this hypothesis.

Megakaryocytes reside in proximity to vascular sinuses (47). This anatomical location may facilitate uptake of circulating proteins. The mechanisms for protein uptake by megakaryocytes are unknown. Injected human lactoferrin was not seen in megakaryocytes, in contrast to albumin and fibrinogen which were injected in smaller amounts. Based on this single observation, megakaryocyte uptake of circulating proteins appears to have specificity. Megakaryocytes have not been examined for an albumin receptor (48). However, megakaryocytes (49) do contain the fibrinogen receptor, glycoproteins IIb-IIIa. It is not known whether GPIIb-IIIa is involved in fibrinogen uptake by megakaryocytes. It is interesting that some patients with Glanzmann's thrombasthenia, who are deficient in GPIIb-IIIa, have an unexplained deficiency of platelet fibrinogen (7). Megakaryocytes and platelets also contain an Fc receptor that may play a role in receptor-mediated endocytosis of IgG (50). However, cells can also take up substances by nonspecific fluid phase mechanisms independent of receptors (51).

Our study does not address whether megakaryocytes synthesize plasma proteins. Although synthesis of IgG by megakaryocytes has not been demonstrated, fibrinogen has been shown to be synthesized by megakaryocytes (9-11). Therefore, it appears that both endogenous synthesis and endocytosis of circulating proteins synthesized by other tissues may contribute to megakaryocyte granule composition.

\section{Acknowledgments}

We wish to express our gratitute for excellent technical assistance to Ms. Valby Chow, Ms. Maria Mena, and Ms. Yvonne Jacques, and for editorial assistance to Ms. Barbara Poetter and Ms. Merle Jolson.

Dr. Handagama is a fellow of the American Heart Association, San Francisco and San Mateo chapter, California affiliate. This research was supported by grant HL-31610 from the National Heart, Lung, and Blood Institute of the National Institutes of Health. 


\section{References}

1. Sander, H. J., J. W. Slot, B. N. Bouma, P. A. Bolhuis, D. S. Pepper, and J. J. Sixma. 1983. Immunocytochemical localization of fibrinogen, platelet factor 4 , and beta thromboglobulin in thin frozen sections of human blood platelets. J. Clin. Invest. 72:1277-1287.

2. Pham, T. D., K. L. Kaplan, and V. P. Butler, Jr. 1983. Immunoelectron microscopic localization of platelet factor 4 and fibrinogen in the granules of human platelets. J. Histochem. Cytochem. 31:905910.

3. Sixma, J. J., A. van den Berg, M. Schiphorst, H. J. Geuze, and J. McDonagh. 1984. Immunocytochemical localization of albumin and factor XIII in thin cryo sections of human blood platelets. Thromb. Haemostasis. 51:388-391.

4. Stenberg, P. E., M. A. Shuman, S. P. Levine, and D. F. Bainton. 1984. Redistribution of alpha-granule and their contents in thrombinstimulated platelets. J. Cell Biol. 98:748-760.

5. Wencel-Drake, J. D., R. G. Painter, T. S. Zimmerman, and M. H. Ginsberg. 1985. Ultrastructural localization of human platelet thrombospondin, fibrinogen, fibronectin, and von Willebrand factor in frozen thin section. Blood. 65:929-938.

6. Cramer, E. M., D. Meyer, R. LeMenn, and J. Breton-Gorius. 1985. Eccentric localization of von Willebrand factor in an internal structure of platelet $\alpha$-granule resembling that of Weibel-Palade bodies. Blood. 66:710-713.

7. George, J. N., A. T. Nurden, and D. R. Phillips. 1984. Molecular defects in interactions of platelets with the vessel wall. $N$. Engl. J. Med. 311:1084-1098.

8. Ryo, R., A. Nakeff, S. S. Huang, M. Ginsberg, and T. F. Deuel. 1983. New synthesis of a platelet-specific protein. Platelet factor 4 synthesis in a megakaryocyte-enriched rabbit bone marrow culture system. J. Cell Biol. 96:515-520.

9. Leven, R. M., P. K. Schick, and A. Z. Budzynski. 1985. Fibrinogen biosynthesis in isolated guinea pig megakaryocytes. Blood. 65:501-504.

10. Belloc, F., P. Hourdille, P. Fialon, M. R. Boisseau, and J. Soria. 1985. Fibrinogen synthesis by megakaryocyte rich human marrow cell concentrates. Thromb. Res. 38:341-351.

11. Uzan, G., G. Courtois, Z. Stanckovic, G. R. Crabtree, and G. Marguerie. 1986. Expression of the fibrinogen genes in rat megakaryocytes. Biochem. Biophys. Res. Commun. 140:543-549.

12. Chiu, H. C., P. K. Schick, and R. W. Colman. 1985. Biosynthesis of Factor $\mathrm{V}$ in isolated guinea pig megakaryocytes. J. Clin. Invest. 75:339-346.

13. Nachman, R., R. Levine, and E. A. Jaffe. 1977. Synthesis of Factor VIII antigen by cultured guinea pig megakaryocytes. J. Clin. Invest. 60:914-921.

14. Handagama, P. J., J. N. George, M. A. Shuman, R. P. McEver, and D. F. Bainton. 1987. Incorporation of a circulating protein into megakaryocyte and platelet granules. Proc. Natl. Acad. Sci. USA. 84:861-865.

15. Handagama, P. J., and D. F. Bainton. 1989. Incorporation of a circulating protein into alpha granules of megakaryocytes. Blood Cells (Berl.). 15:59-72.

16. Leary, J. J., D. J. Brigati, and D. C. Ward. 1983. Rapid and sensitive colorimetric method for visualizing biotin-labeled DNA probes hybridized to DNA or RNA immobilized on nitrocellulose: Bio-blots. Proc. Natl. Acad. Sci. USA. 80:4045-4049.

17. Beckstead, J. H., P. E. Stenberg, R. P. McEver, M. A. Shuman, and D. F. Bainton. 1986. Immunohistochemical localization of membrane and alpha-granule proteins in human megakaryocytes. Application to plastic-embedded bone-marrow biopsy specimens. Blood. 67:285-293.

18. George, J. N., S. Saucerman, S. P. Levine, L. K. Knieriem, and D. F. Bainton. 1985. Immunoglobulin $\mathrm{G}$ is a platelet alpha granule-secreted protein. J. Clin. Invest. 76:2020-2025.
19. Reynolds, E. S. 1963. The use of lead citrate at high $\mathrm{pH}$ as an electron-opaque stain in electron microscopy. J. Cell Biol. 17:208212.

20. Bainton, D. F., L. J. Miller, T. K. Kishimoto, and T. A. Springer. 1987. Leukocyte adhesion receptors are stored in peroxidase-negative granules of human neutrophils. J. Exp. Med. 166:16411653.

21. George, J., and S. Saucerman. 1988. Platelet IgG, IgA and albumin. Correlation of platelet and plasma concentrations in normal subjects and in patients with ITP or dysproteinemia. Blood. 72:362365.

22. Shepard, J. M., S. K. Goderie, N. Brzyski, P. J. Del Vecchio, A. B. Malik, and H. K. Kimelberg. 1987. Effects of alterations in endothelial cell volume on transendothelial albumin permeability. $J$. Cell. Physiol. 133:389-394.

23. Dvorak, A. M., H. F. Dvorak, and M. J. Karnovsky. 1972. Uptake of horseradish peroxidase by guinea pig basophilic leukocytes. Lab. Invest. 26:27-39.

24. Dvorak, A. M., S. J. Klebanoff, W. F. Henderson, R. A. Monahan, K. Pyne, and S. J. Galli. 1985. Vesicular uptake of eosinophil peroxidase by guinea pig basophils and by cloned mouse mast cells and granule-containing lymphoid cells. Am. J. Pathol. 118:425-438.

25. De Bruyn, P. P. H., S. Michelson, and P. W. Bankston. 1985. In-vivo endocytosis by bristle-coated pits and intracellular transport of endogenous albumin in the endothelium of the sinuses of liver and bone marrow. Cell Tissue Res. 240:1-7.

26. Milici, A. J., N. E. Watrous, H. Stukenbrok, and G. E. Palade. 1987. Transcytosis of albumin in capillary endothelium. J. Cell Biol. 105:2603-2612.

27. Rothschild, M. A., A. Bauman, R. S. Yalow, and S. A. Berson. 1955. Tissue distribution of $I^{131}$-labeled human serum albumin following intravenous administration. J. Clin. Invest. 34:1354-1358.

28. Waldman, T. A., and W. Strober. 1969. Metabolism of immunoglobulins. Prog. Allergy. 13:1-110.

29. Takeda, Y. 1966. Studies of the metabolism and distribution of fibrinogen in healthy men with autologous ${ }^{125}$ I-labeled fibrinogen. $J$. Clin. Invest. 45:103-111.

30. Yokota, S. 1983. Immunocytochemical evidence for transendothelial transport of albumin and fibrinogen in rat heart and diaphragm. Biomed. Res. 4:577-586.

31. Koch-Weser, J., and E. M. Sellers. 1976. Drug therapy: binding of drugs to serum albumin. N. Engl. J. Med. 294:526-531.

32. James, H. L., P. Ganguly, and C. W. Jackson. 1977. Characterization and origin of fibrinogen in blood platelets: a review with recent data. Thromb. Haemostasis. 38:939-954.

33. Solum, N. O., and S. Lopaciuk. 1969. Bovine platelet proteins. II. Purification of platelet fibrinogen. Thromb. Diath. Haemorrh. 21:428-440.

34. Ganguly, P. 1972. Isolation and some properties of fibrinogen from human blood platelets. J. Biol. Chem. 247:1809-1816.

35. James, H. L., and P. Ganguly. 1975. Identity of human platelet fibrinogen. Biochem. Biophys. Res. Commun. 63:659-662.

36. Plow, E. F., and T. S. Edgington. 1975. Unique immunochemical features and intracellular stability of platelet fibrinogen. Thromb. Res. 7:729-742.

37. Simpson, P. J., L. A. Sporn, C. W. Francis, F. Collichio, and V. J. Marder. 1987. Evidence that megakaryocyte and hepatocyte origins of human fibrinogen differ in 57.5 chain content. Blood. 70:395a. (Abstr.)

38. Nachman, R. L. 1965. Immunologic studies of platelet protein. Blood. 25:703-711.

39. Castaldi, P. A., and J. Caen. 1965. Platelet fibrinogen. J. Clin. Pathol. 18:579-585.

40. Doolittle, R. F., T. Takagi, and B. A. Cottrell. 1974. Platelet and plasma fibrinogens are identical gene products. Science (Wash. DC). 185:368-370. 
41. Kunicki, T. J., P. J. Newman, D. L. Amrani, and M. W. Mosesson. 1985. Human platelet fibrinogen. Purification and hemostatic properties. Blood. 66:808-815.

42. Karpatkin, M., L. Howard, and S. Karpatkin. 1984. Studies of the origin of platelet-associated fibrinogen. J. Lab. Clin. Med. 104:223-237.

43. Davey, M. G., and E. F. Luscher. 1966. Platelet proteins. In Biochemistry of Blood Platelets. E. Kowalski and S. Niewiarowski, editors. Academic Press, New York. 9-22.

44. Leporrier, M., G. Dighiero, M. Auzemery, and J. L. Binet. 1979. Detection and quantification of platelet-bound antibodies with immunoperoxidase. Br. J. Haematol. 42:605-611.

45. LoBuglio, A. F., W. S. Court, L. Vinocur, G. Maglott, and G. M. Shaw. 1983. Immune thrombocytopenic purpura: use of a ${ }^{125} \mathrm{I}-$ labeled antihuman IgG monoclonal antibody to quantify plateletbound IgG. N. Engl. J. Med. 309:459-463.

46. George, J. N. 1989. The origin and significance of platelet IgG. In Platelet Immunobiology: Molecular and Clinical Aspects. T. J. Ku- niki and J. N. George, editors. J. B. Lippincott Co., Philadelphia. 305-336.

47. Lichtman, M. A., J. K. Chamberlain, W. Simon, and P. A. Santillo. 1978. Parasinusoidal location of megakaryocytes in marrow: a determinant of platelet release. Am. J. Hematol. 4:303-312.

48. Weisiger, R., J. Gollan, and R. Ockner. 1981. Receptor for albumin on the liver cell surface may mediate uptake of fatty acids and other albumin-bound substances. Science (Wash. DC). 211:10481051.

49. Rabellino, E. M., R. B. Levene, L. L. K. Leung, and R. L. Nachman. 1981. Human megakaryocytes. II. Expression of platelet proteins in early marrow megakaryocytes. J. Exp. Med. 154:88-100.

50. Moore, A., G. D. Ross, and R. L. Nachman. 1978. Interaction of platelet membrane receptors with von Willebrand factor, ristocetin, and the Fc region of immunoglobulin G. J. Clin. Invest. 62:10531060.

51. Steinman, R. M., I. S. Mellman, W. A. Muller, and Z. A. Cohn. 1983. Endocytosis and the recycling of plasma membrane. J. Cell Biol. 92:1-27. 